\title{
Basic Principles and Standardization of Intraoperative Nerve Monitoring in Thyroid Surgery
}

\author{
Mehmet Uludag ${ }^{1}$, Nurcihan Aygun ${ }^{2}$, Cemal Kaya ${ }^{1}$, Mert Tanal$^{1}$, Sibel $\mathrm{Oba}^{3}$, Adnan Isgor ${ }^{5}$
}

\begin{abstract}
:
Basic principles and standardization of intraoperative nerve monitoring in thyroid surgery

Voice changes after thyroid surgery are frequent and one of the most important complications. Both the recurrent laryngeal nerve (RLN) and the external branch of the superior laryngeal nerve (EBSLN) must be preserved to minimize the patient's voice and respiratory problems after surgery. Intraoperative neuromonitoring (IONM) is a method based on dynamically evaluating motor function of the nerve during surgery in addition to the visual identification of the nerve. Intraoperative neuromonitoring was introduced 50 years ago in thyroid surgery and IONM via endotracheal tube with surface electrodes has become a standard applied method for reasons such as convenience, simplicity, non-invasiveness and safety, and nowadays is used in thyroid surgery. The use of IONM for RLN and EBSLN is increasing in thyroid surgery. Experience and standardization is essential for proper use of IONM for both anesthesiologist and surgeon. In this context, the learning curve for both surgeons and anesthetists is about 50-100 cases. Intraoperative neuromonitoring makes a significant contribution to the identification and functional evaluation of both RLN and EBSLN. RLN monitorisation can be performed intermittently with the monitoring probe or continuously with the aid of a probe applied to the vagus. Standardization of RLN monitoring includes the vocal cord examination via preoperative laryngoscopy (L1), getting signals from ipsilateral vagus prior to RLN dissection (V1), stimulation of RLN at the first point found in the tracheoesophageal groove (R1), stimulation of the RLN from the most proximal point it was revealed after the dissection was completed (R2), vagus stimulation after surgical site bleeding control is complete (V2), vocal cord examination via postoperative laryngoscopy (L2). V2 is the most appropriate test to predict postoperative vocal cord function. In the intermittent IONM of RLN, only the nerve stimulated by the probe and the point that the nerve is stimulated inform about the function of the distal part. Continuous IONM allows continuous follow-up of RLN function while dissecting the thyroid gland by continuous stimulation of the RLN with the probe applied to the vagus at the neck before RLN leaves the vagus. Primarily in EBSLN monitoring, the contraction of the cricothyroid muscle, which is located in the surgical field and whose motor neuron is EBSLN, is evaluated. Intraoperative neuromonitoring is a method that contributes to many aspects of thyroidectomy and increases the standards of thyroidectomy, together with significant contribution to the detection and functional evaluation of both RLN and EBSLN.

Keywords: Intraoperative neuromonitoring, recurrent laryngeal nerve, external branch of the superior laryngeal nerve
\end{abstract}

ÖZET:

Tiroit cerrahisinde intraoperatif sinir monitorizasyonunun temel prensipleri ve standardizasyonu

Tiroit cerrahisi sonrası oluşan sesle ilgili problemler sık ve en önemli komplikasyonlardandır. Cerrahi sonrası hastanın ses ve solunum problemlerini minimalize edebilmek için hem reküren laringeal sinirin (RLS) hem de süperior laringeal sinirin eksternal dalının (SLSE) korunması gerekir. İntraoperatif nöromonitorizasyon (IONM) sinirin gözle görülmesine ek olarak ameliyat sırasında sinirin motor fonksiyonlarının dinamik olarak değerlendirilmesi temeline dayanan bir yöntemdir. Tiroit cerrahisinde IONM 50 yıl önce kullanılmaya başlanmış ve yüzey elektrotlu endotrakeal tüp ile iONM; amaca uygunluk, basitlik, noninvazif olma ve güvenlilik gibi nedenlerle standart uygulanan yöntem haline gelmiş olup, günümüzde tiroit cerrahisinde bu yöntem kullanılmaktadır. Tiroit cerrahisinde RLS ve SLSE için iONM kullanımı giderek artmaktadır. IONM'nin uygun kullanımı için hem anestezist hem cerrah için deneyim ve standardizasyonu şarttır. Bu bağlamda hem cerrahların hem de anestezistler için öğrenme eğrisi yaklaşık 50-100 arası olgudur. iONM hem RLS hem SLSE'nin bulunmasında ve fonksiyonel olarak değerlendirilmesinde önemli katkı sağlar. RLS monitorizasyonu monitorizasyon probu ile aralıklı veya vagusa uygulanan prob yardımı ile sürekli olarak uygulanabilir. RLS monitorizasyonunun standardizasyonu; preoperatif laringoskopi ile vokal kord muayenesi (L1), RLS diseksiyonu öncesi aynı taraf vagustan uyarı alınması (V1), RLS'nin trakeaozefageal olukta ilk bulunduğu noktada uyarılması (R1), diseksiyon bittikten sonra RLS'nin ortaya konduğu en proksimal noktasından uyarılması (R2), cerrahi alanda kanama kontrolü tamamlandıktan sonra vagusun uyarılması (V2), postoperatif laringoskopi ile vokal kord muayenesini (L2) içerir. V2 postoperatif vokal kord fonksiyonunu öngörmede en uygun testtir. RLS aralıklı iONM'sinde sadece sinirin probla uyarıldığı an ve sinirin uyarıldığı nokta distalinin fonksiyonu hakkında bilgi verir. Sürekli iONM ise RLS'nin vagustan ayrılmadan önce boyunda vagusa uygulanan probla yapılan devamlı uyarı sayesinde cerraha tiroidi diseke ederken RLS fonksiyonunun sürekli takip edilmesini sağlar. SLSE monitorizasyonunda primer olarak ameliyat sahasında bulunan ve SLSE'nin motor siniri olduğu krikotiroid kasın kasılması değerlendirilir. IONM hem RLS hem SLSE'nin bulunmasında ve fonksiyonel olarak değerlendirilmesinde önemli katkı sağlaması ile birlikte tiroidektomiye birçok açıdan katkı sağlayan ve tiroidektominin standartlarını arttıran bir yöntemdir.

Anahtar kelimeler: İntraoperatif nöromonitorizasyon, reküren laringeal sinir, süperior laringeal sinirin eksternal dalı

Ş.E.E.A.H. Tıp Bülteni 2017;51(1):13-25
${ }^{1}$ Sisli Hamidiye Etfal Training and Research Hospital, Department of General Surgery, Istanbul - Turkey

${ }^{2}$ Siverek State Hospital, Sanliurfa - Turkey ${ }^{3}$ Sisli Hamidiye Etfal Training and Research Hospital, Department of Anesthesiology and Reanimation, Istanbul - Turkey ${ }^{4}$ Bahçeşehir University, Faculty of Medicine, Department of General Surgery, Istanbul - Turkey

Address reprint requests to / Yazışma Adresi: Mehmet Uludag,

Sisli Hamidiye Etfal Training and Research Hospital, Department of General Surgery, Istanbul - Turkey

\section{E-mail / E-posta:}

drmuludag@hotmail.com

Date of receipt / Geliş tarihi:

February 16, 2017 / 16 Şubat 2017

Date of acceptance / Kabul tarihi: February 16, 2017 / 16 Şubat 2017 


\section{INTRODUCTION}

Voice changes after thyroid surgery are frequent and one of the most important complications. Both the recurrent laryngeal nerve (RLN) and the external branch of the superior laryngeal nerve (EBSLN) must be preserved to minimize the patient's voice and respiratory problems after surgery. The gold standard method currently used to protect RLN during thyroid and parathyroid surgery is the routine visualization of the nerve, following its course at the operation site and its anatomical preservation (1). However, anatomical preservation of the nerve does not indicate that it's functionally preserved. The intraoperative detection rate of nerve paralysis causing vocal cord paralysis does not exceed $15 \%$ (2). Intraoperative neuromonitoring (IONM) is a method based on the visualization of the nerve in addition to the dynamic evaluation of the nerve's motor functions during surgery (3). In thyroid surgery, IONM was introduced 50 years ago and various nerve monitoring methods such as glottic pressure method, glottic monitoring method, insertion of needle electrodes in vocal cords endoscopically or through cricothyroid membrane, laryngeal palpation method and monitoring via endotracheal tube with surface electrodes were used (4-6). IONM via endotracheal tube with surface electrodes has become a standard applied method for reasons such as convenience, simplicity, noninvasiveness and safety, and nowadays it is used in thyroid surgery (3). The use of IONM is increasing in thyroid surgery (7-9). The knowledge of basic principles of the system, experience and standardization are required for the proper use of the IONM and improvement of its results. A guide has been published by the International Neural Monitoring Study Group on standardization and implementation of the system (3). In this study, we aimed to evaluate the basic principles and standardization of IONM in thyroid surgery.

\section{INTRAOPERATIVE NERVE MONITORING VIA ENDOTRACHEAL TUBE WITH SURFACE ELECTRODES}

Intraoperative neuromonitoring via endotracheal tube with surface electrodes is an electromyography
(EMG) method that evaluates the vocal cord adductor function by surface electrodes on the endotracheal tube. Almost all of today's monitoring systems are giving signals both as audible and visual EMG waveforms (3). As known, the laryngeal adductor muscles consist of the thyroarytenoid muscle (voice muscle), the lateral cricoarytenoid muscle and the interarytenoid muscle. Posterior cricoarytenoid muscle is the main abductor of the vocal cord. Basically, endotracheal tube-based monitoring with surface electrodes is based on the monitoring of the thyroarytenoid muscle, which is the main adductor of the vocal cord. With nerve stimulation, the system gives both audible and recordable EMG signals.

Parts forming the monitoring systems are shown in Table-1 and Picture-1, Picture-2 (a,b,c,d,e). The system basically consists of the combination of 2 electrical circuits as the stimulation and recording sides (Figure-1) $(3,10)$. The stimulation side consists of a stimulator probe (Nerve stimulator probe, continuous vagus stimulator probe) produced by the

\section{Table-1: Parts of the monitoring system}

Monitor
Interface-connector box
Endotracheal tube with surface electrodes
Stimulator probes
$\quad$ Nerve stimulation probe
Continuous vagus stimulator probe

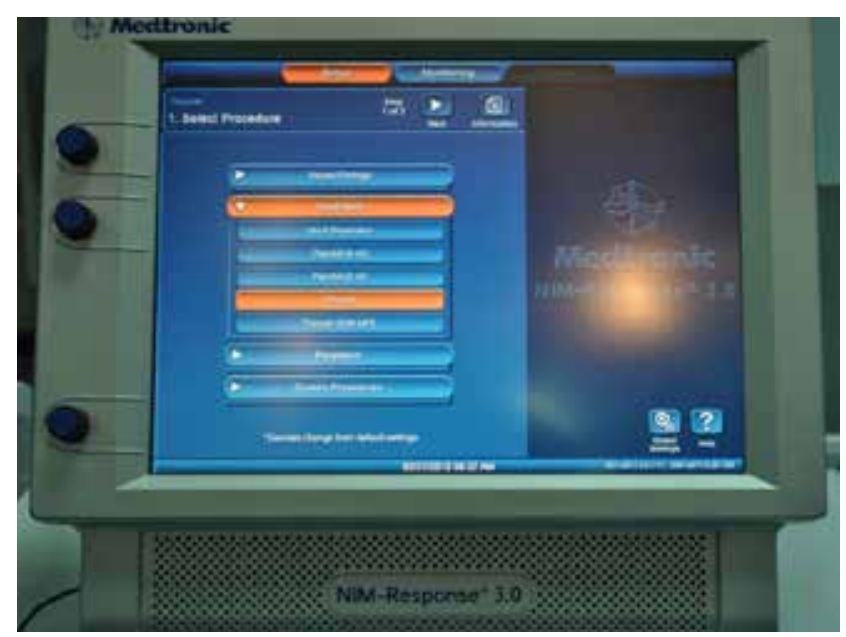

Picture-1: Intraoperative neuromonitoring monitor (Medtronic NIM-Response 3.0) (Medtronic Xomed, Jacksonville, $\mathrm{FL}$, USA) 

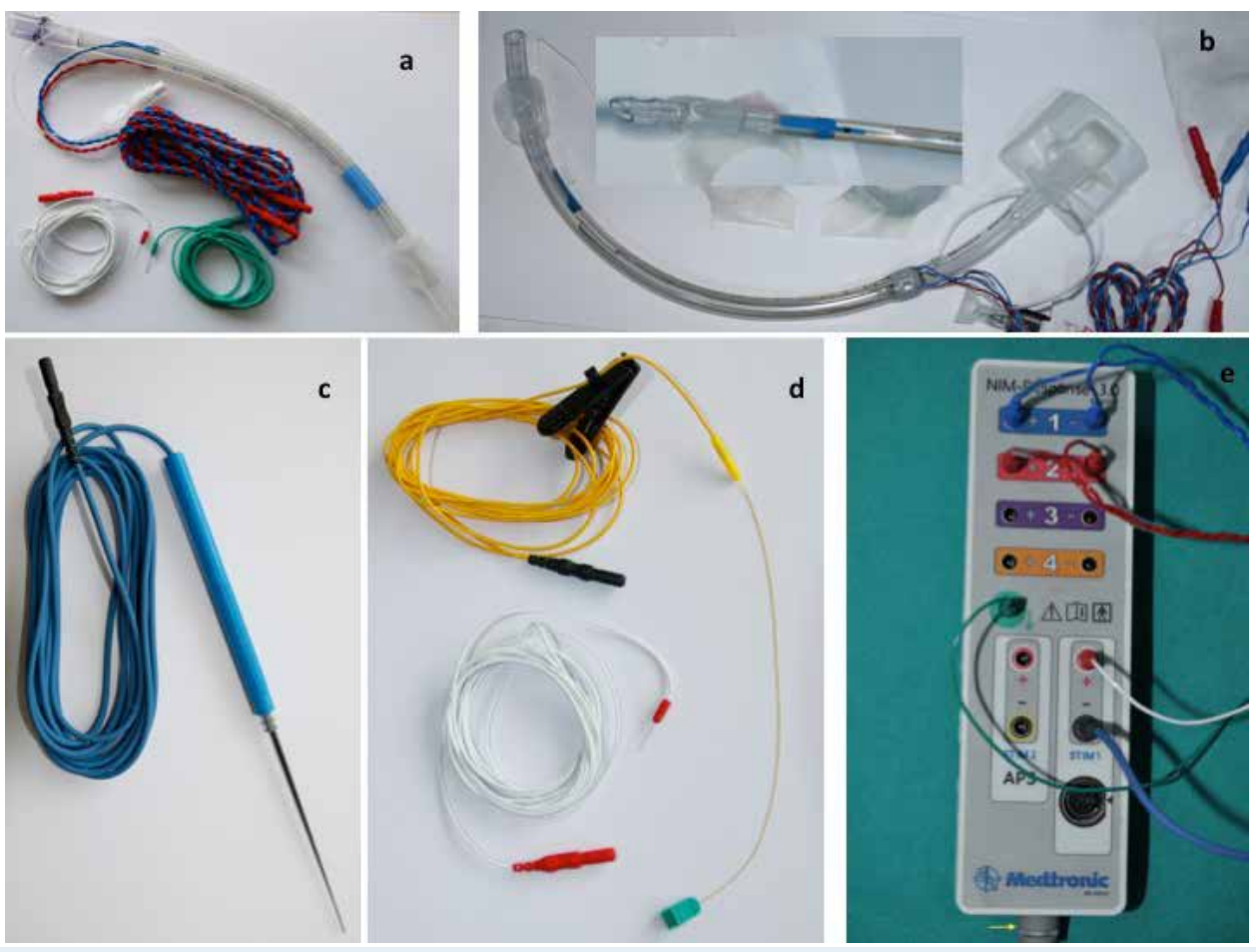

Picture-2: For intraoperative neuromonitoring, a) standard surface electrode tube with a pair of recording electrodes , stimulatory (white) and recording (green) grounding electrodes b) Triventage tube with increased electrode surface c) monopolar stimulator probe, d) continuous vagus stimulator (APS: Automatic periodic stimulation) probe and grounding electrode of Medtronic (Medtronic Xomed, Jacksonville, FL, USA) company

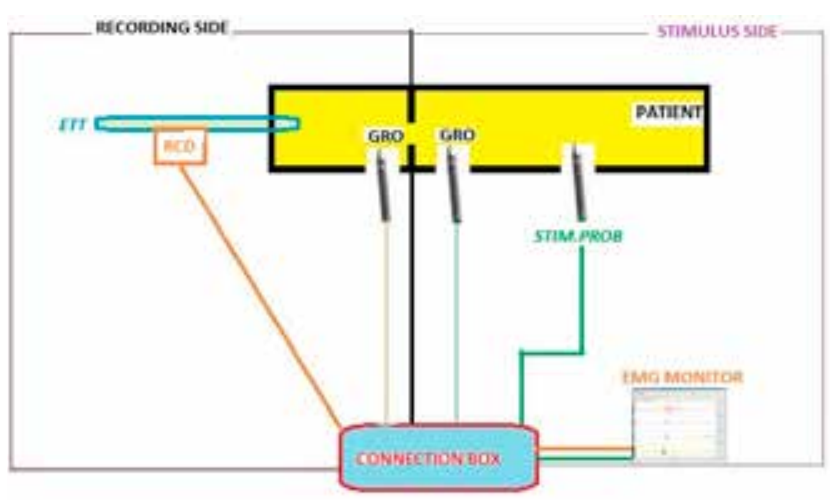

Figure-1: Schematic view of the monitoring system generated by recording and stimulation (EMG: Electromyography, ETT: Endotracheal tube, RE: Recording electrodes, GE: Grounding electrodes, SP: Stimulator probe)

system and transmitting electric current at the desired level to the nerve, and a grounding cable in monopolar systems. The stimulation probes can be either monopolar or bipolar. Continuous monitoring probes applied to the vagus can be monopolar, bipolar and triopolar. However, the recording part consists of recording probes on the endotracheal tube which are placed at the vocal cords level and their ground loop. These two main systems combine on the interconnect box, connect to the monitor via the interconnect box, and the system integrity is ensured. Monitorisation systems are also used in ENT and neurosurgery operations for the monitoring of peripheral nerves other than thyroid surgery. The monitoring systems can be with 2, 4, 8 or 16 channels. The number of channels also indicates the number of nerves that can be monitored. A separate EMG screen opens on the screen for each monitored nerve. Two channels for the right and left vocal cords are sufficient in thyroid surgery and 2 EMG screens appear on the screen (Picture-3a). If the patient is to undergo continuous vagus stimulation at the same time, 2 channels for intermittent monitoring on the left side of the screen and another screen for continuous vagus stimulation on the right side open (Picture-3b). 


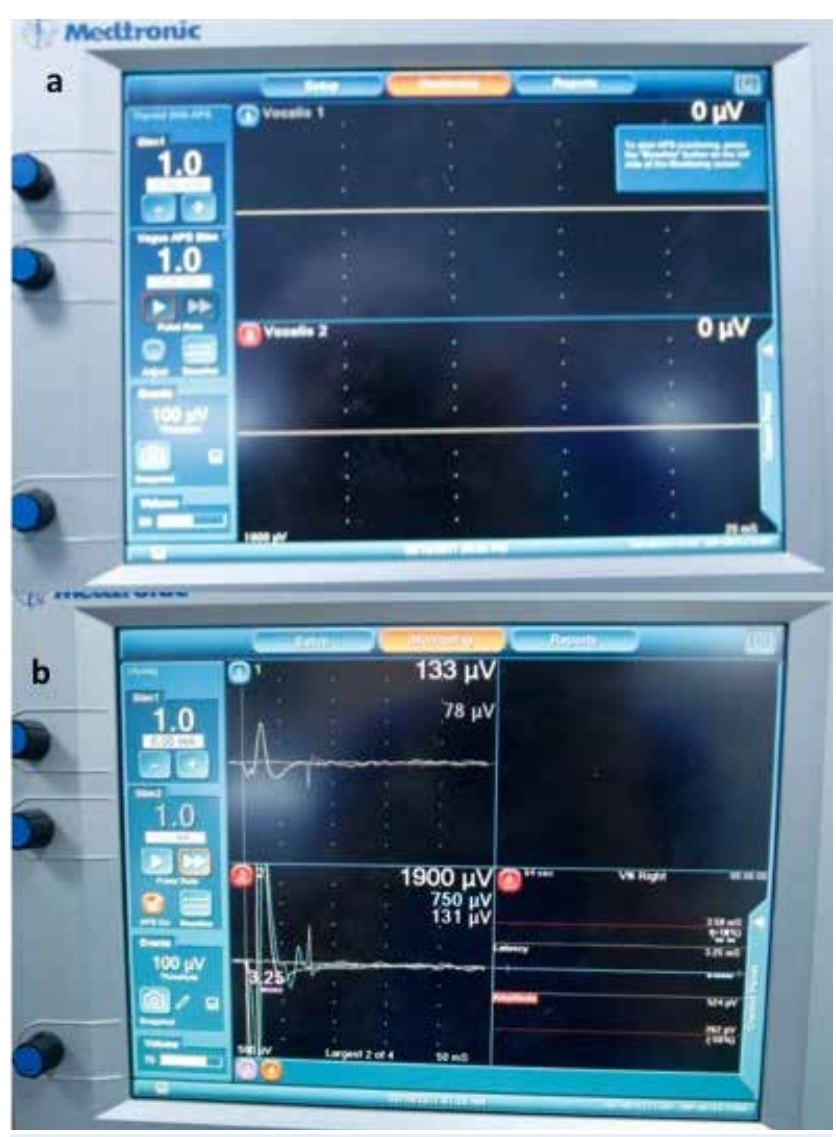

Picture-3: a) Two EMG channels opened at the monitor screen of Medtronic NIM-Response 3.0: 1 (blue) left vocal cord; 2 (red) right vocal cord. b) Two EMG channels that opened at the left when continuous vagus stimulation is performed with Medtronic NIM-Response 3.0 device, follow-up screen for continuous vagus stimulator probe opened for right vagus at the bottom right

\section{INTUBATION AND PREPARATION OF THE PATIENT}

Experience and standardization are essential for proper use of intraoperative nerve monitoring (IONM). In this context, both surgeons and anesthetists need to learn the system and method and gain experience. It is stated that the learning curve needs to be composed of approximately 50-100 cases in order to reach the safe technique and to correct some variables at this period (11-13). Since neuromuscular blockers affect muscle contraction and associated monitoring, muscle relaxants should not be used in these patients except for muscle relaxant to be used for intubation. If rocuronium, which is of nondepolarizing agents, is administered in standard doses $(0.6 \mathrm{mg} / \mathrm{kg})$ in these patients, the effect on the EMG amplitude improves by $80 \%$ in 29 minutes, and it takes more than 1 hour for its effect to completely disappear. After intubation, the muscle relaxant effect of rocuronium with suggamadex at $2 \mathrm{mg} / \mathrm{kg}$ is eliminated within 5 minutes and high EMG amplitude can be obtained at the beginning of the operation (14). For intubation, $0.3 \mathrm{mg} / \mathrm{kg}$ low dose rocuronium is sufficient for most patients. $80 \%$ of this dose effect is eliminated in 15 minutes. After this step, the patient's anesthesia is provided by inhaler and intravenous anesthesia. These agents do not have significant effects on EMG at doses provided by adequate depth of anesthesia. The largest tube that can be passed between the patient's vocal cords is selected to provide the ideal fit of the intubation tube to the vocal cords. The thinner tube may cause technical problems in monitoring due to contact problems that may occur with vocal cords. There may be saliva accumulation at the level of vocal cords, which can cause signal changes in the monitoring. Glycopyrrolate may be used to reduce saliva, tracheobronchial and pharyngeal secretions and gastric acidity and/or intraoperative aspiration may be performed to prevent this (3). While the tube is inserted, the blue section where the electrodes are open in the standard tube, and the blue line in the front middle in the tube where the electrode surfaces are increased, should be at the level of the vocal cords. It is important that the tube is in its normal position for proper and optimum amplitude. Changes in the rotation or depth of the tube cause significant decreases in the amplitude value, but do not change the latency time $(15,16)$. After the tube is inserted, the patient is given an operation position by applying a shoulder pillow and extension to the head. During positioning, the anesthetist must protect the tube by holding it in order to keep its position unchanged. If the tube is fixed to the rim of the patient's mouth before the patient is positioned, the position of the tube in the airway may change when the patient's position is changed from neutral position to extension position. Yap et al. (17) reported that the neck can be displaced up to $21 \mathrm{~mm}$ deep, $33 \mathrm{~mm}$ outward maximum after the neck has been positioned at extension. Accordingly, the tube can move about $6.5 \mathrm{~cm}$ during position change. This can lead to the disruption of the relationship between the surface electrodes which are located in a $3 \mathrm{~cm}$ area during positioning and the vocal 


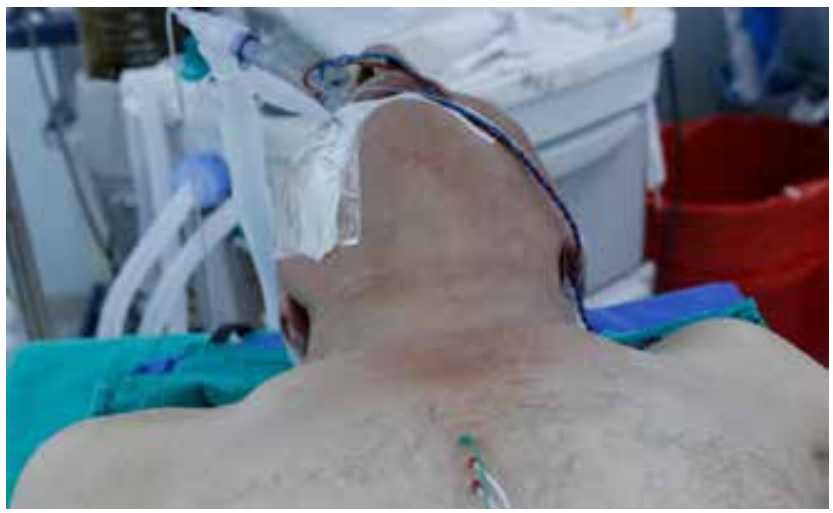

Picture-4: After the patient is intubated with endotracheal tube with surface electrodes and positioned, the tube is fixed and application of subcutaneous grounding electrodes to the presternal region (Green: Grounding electrode of recording electrodes on endotracheal tube, 2 white: The grounding electrodes of the monopolar stimulator probe and the continuous vagus stimulator probe

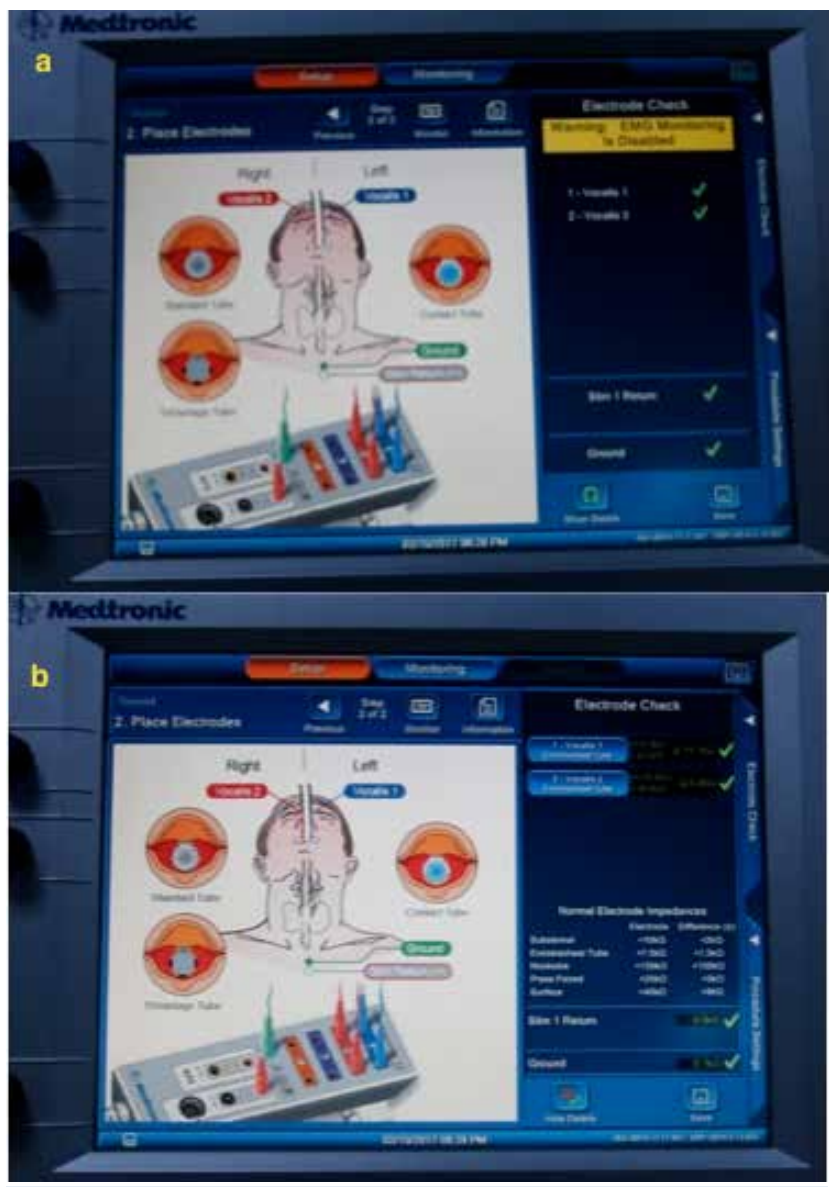

Picture-5: After the patient is intubated and the stimulating and recording connections are connected to the device via the connection box,on the screen a) control of connections of recording and stimulating electrodes, b) control of electrode resistances cords. Not placing the tube in the ideal position causes the amplitude to be obtained from the vocal cord to change significantly. The tube should be secured to the rim of the lip after the patient is in full position. The grounding electrodes of the recording electrodes and the stimulating electrodes are subdermally applied to the presternal region (Picture-4) or to the shoulder at the side of the monitor. The recorder grounding electrode should be located closer to the surgical field upper, and the stimulating grounding electrode should be placed 1-2 cm below this. After all connections are made, the circuit integrity is checked from the monitor by electrode control and the electrode resistance level on the line is checked from the device (Picture-5a, b). For each electrode this value should be less than $5 \mathrm{k} \Omega$. Furthermore, the resistance difference between cathode and anode electrodes of a channel must be less than 1 $k \Omega$. A high resistance difference in the endotracheal tube electrodes may indicate that the contact between the patient and the endotracheal tube is not adequate and may require replacement of the endotracheal tube for adjustment (3). Once the patient is positioned, the tube location must be verified by verification tests.

\section{Verification Tests for the Location of the Tube}

Respiratory changes: In the short-term window period before the lost of the effect of short-acting neuromuscular agents and the deepening of anesthesia with inhalation anesthesics following intubation, 30-70 $\mu \mathrm{V}$ amplitude spontaneous respiratory movements are initiated. During this period, waveforms occur at the amplitude of 30-70 $\mu \mathrm{V}$ on the monitor. If these respiratory changes are detected in both vocal cords, anesthesia can be deepened and the operation can be continued. If no respiratory changes can be detected, the position of the tube should be assessed by laryngoscopy and corrected if necessary (18).

Repeat laryngoscopy: Although it is the most appropriate method for evaluating the tube position, it requires a secondary intervention (19).

The monitor should be set as follows; threshold value: $100 \mu \mathrm{V}$, excitation electrode stimulation level: 0.5-2 mA (mean: $1 \mathrm{~mA}$ ), vibration frequency: $30 \mathrm{~Hz}, 4$ stimulations per second, stimulation period: $100 \mu \mathrm{s}(20)$. 


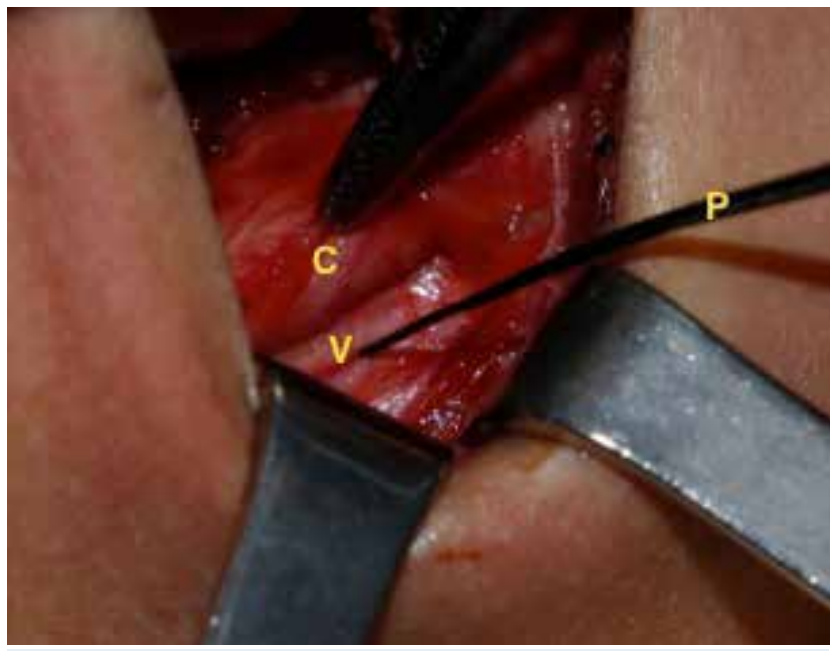

Picture-6: The first vagus stimulation (V1) obtained before entering the thyroid region (P: Probe, V: Vagus)

\section{Surgical Field Initial Tests}

Stimulation of strap muscles with probe: After the initiation of the surgery, the strap muscles are directly stimulated by probe, following the incision. The visualization of the contraction of strap muscles with stimulation indicates that the effect of muscle relaxant has passed and that the stimulated side of the system is functioning normally (5).

Table-2: Monitoring methods of RLN and EBSLN

- Monitoring of RLN

- Intermittent

- Continuous

- Monitoring of EBSLN

- Intermittent
Ipsilateral vagus stimulation: Without entering the thyroid region, the ipsilateral vagus is dissected in the carotid sheath and stimulated with probe (V1) (Picture 6). Vagus-stimulated signaling from the vocal cord indicates both the stimulation and the recording side of the system work properly. In this case, it should be considered that the RLN can be searched by the neural mapping described below. This means that if the tissue stimulated is thought to be a nerve, then it means that a positive signal is received (5).

\section{RLN and EBSLN MONITORING METHODS}

Recurrent laryngeal nerve (RLN) monitoring can be performed intermittently with the aid of a monitoring probe or continuously with probe applied to vagus. The external branch of superior laryngeal nerve is at risk during upper pole dissection due to its close association with superior thyroid vessels. The external branch of superior laryngeal nerve can be monitorized with an intermittent monitoring probe. It is not possible to apply a continuous vagus probe to the proximal of the point which the EBSLN leaves, due to its proximity to the base of the head and outside of the thyroidectomy area (10).

\section{STANDARDIZATION OF INTRAOPERATIVE NERVE MONITORING}

This process should be standardized for a successful and safe IONM. Chiang et al. (19) have

\section{Table-3: Standard steps of RLN and EBSLN monitoring in intraoperative nerve monitoring}

\begin{tabular}{lll}
\hline Stage & Symbol & Procedure \\
\hline I & L1 & Vocal cord examination with preoperative laryngoscopy \\
II & V1 & Stimulation of the ipsilateral vagus with a current above the threshold value (1-2 mA) before RLN dissection \\
III & R1 & Stimulation of RLN at the first point where it is found in the tracheoesophageal groove \\
& S1 & Stimulation of EBSLN with a probe after it has been detected \\
& S2 & Stimulation of EBSLN proximal to the point where superior thyroid vessels are separated, following the separation \\
& of the vessels and bleeding control is complete
\end{tabular}

(RLN: Recurrent laryngeal nerve, EBSLN: External branch of superior laryngeal nerve) 
defined a 4-step method for IONM standardization. The International IONM Study Group presented the standard IONM stages by adding preoperative and postoperative vocal cord examinations to the IONM phases defined by Chiang et al. (Table-3) (3). These standards relate to RLN monitoring. The external branch of SLN monitoring is also increasing in thyroid surgeries. Dionigi et al. (21) suggested adding standards related to EBSLN monitoring (S1, S2) to IONM standards. We suggest that these standards will be added to the monitoring standards in the near future. Thus, these standards are given as a whole in Table-3. But S1 and S2 are not numbered.

\section{DEFINITION OF ELECTROMYOGRAPHIC WAVEFORM PROPERTIES IN INTRAOPERATIVE NERVE MONITORING}

The amplitude and latency time of the EMG waveforms are basically evaluated in the intraoperative nerve monitoring. For this reason, the definition of these two concepts will be referred to.

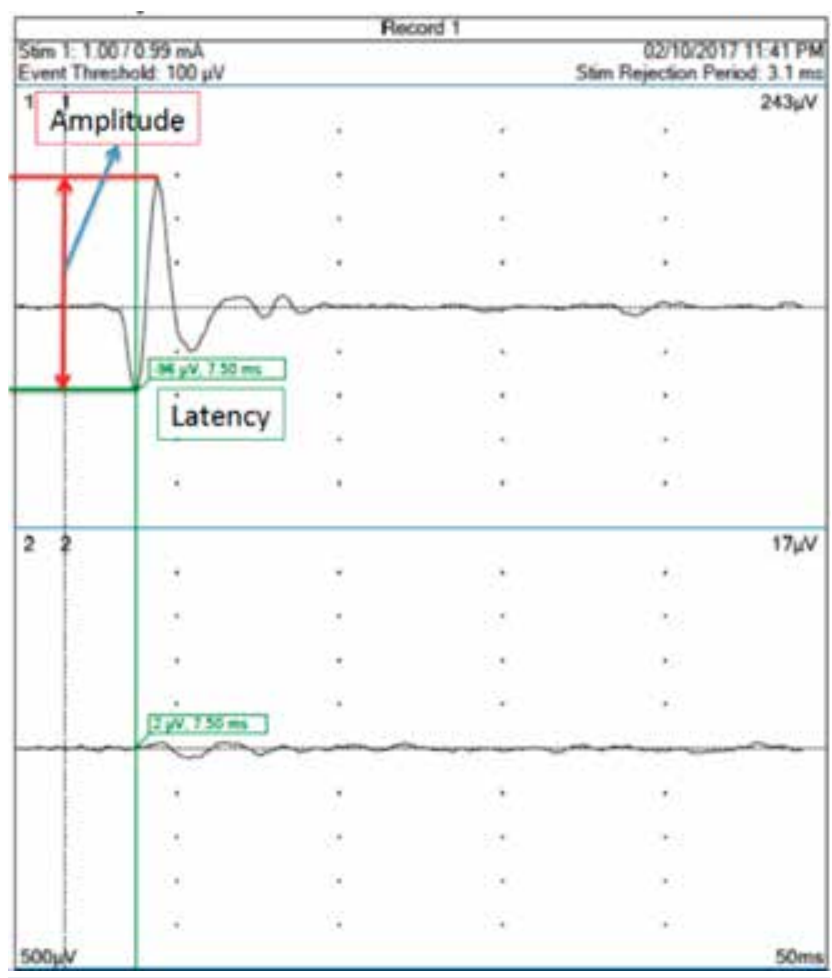

Figure-2: Amplitude and latency time of biphasic EMG wave recorded from vocal cord with left vagus stimulation
Amplitude: The typical biphasic sinusoidal waveform represents the sum of the motor unit activation potentials of the ipsilateral vocal cord muscle. The basic waveform formed by stimulation of human RLN and vagus nerve is biphasic or triphasic. The amplitude of the waveform that is monitored according to current standards in EMG monitor physiology can be defined as the magnitude between the positive highest point and the negative lowest point of the biphasic wave (Figure-2) (3).

Latency: There is no single standard definition for this in surgical monitoring. According to the definition made by the International Intraoperative Monitorization Working Group; because the deviation of the waveform from the zero line may be very variable when the wave is formed, the time between waveform endpoint that is generated at the time the stimulation is performed and the first peak point (negative or positive) of the EMG waveform after its deviation from the zero line is considered (Figure-3) (3). Because the distance to the target muscle is greater than the RLN in the thyroid bed, when the vagus is stimulated,

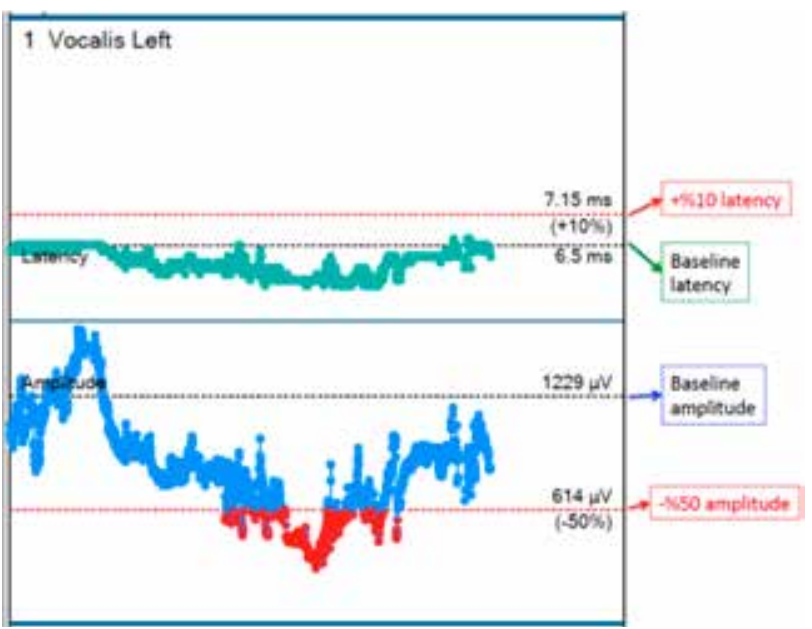

Figure-3: The graph obtained on the screen with the continuous vagus probe (APS) applied to the left vagus (Dotted black lines: Baseline amplitude (lower dotted line) and delay time (upper dotted line) values, Red dotted line: The value of delay time (latency) which is $10 \%$ above the baseline value (upper dotted red line), Amplitude value below $50 \%$ of the baseline amplitude value (lower dotted red line), Green graph: The course of latency time during the operation, Blue graph: The course of the amplitude values during the operation (It occurs when occasionally the red graphic amplitude value falls below $50 \%$ of baseline activity. At the same time it gives an audible warning.) 
the latency time is longer than the RLN in vagus. In addition, because of the different lengths of both RLNs and the left RLN is longer, the left vagus latency time is longer in the neck vagus stimulation than the right.

Signal Loss: According to the standards of the international guidelines and the literature, if the EMG amplitude of the vocal cord is below $100 \mu \mathrm{V}$ by stimulation of the nerve with a current above the threshold level (eg 1-2 mA) at a dry region, and/or the absence of an audible warning tone, is defined as signal loss (3). In order to be able to evaluate IONM signals safely, the standards recommended by the manual should be complied with and these steps ( $L 1$, V1, R1, R2, V2, L2) must be applied. To determine the type of signal loss, the point at which the signal is lost should be determined by stimulating the RLN proximal to the point where it enters the larynx.These are;

Type 1 Signal Loss: It is known as segmental signal loss. It is the loss of signal at a certain point in the nerve. That is, the signal is obtained distal to a point where the nerve is traumatized (on the larynx side) by stimulating with the IONM probe. No signal is detected by probe stimulus from the proximal to the traumatic point.

Type 2 Signal Loss: It is known as global signal loss. This type does not have a specific damage point. No signal is acquired during the entire course of the RLN and with vagus stimulation.

Intraoperative Signal Recovery: Especially with the introduction of the IONM with continuous vagus stimulation, it has been shown that in some patients with signal loss, the signal can be improved. If the signal exceeds $50 \%$ of the initial amplitude after signal loss has developed, full signal recovery is defined as partial signal improvement if the signal is above 100 $\mu \mathrm{V}$ but is below $50 \%$ of the initial amplitude (22).

\section{APPLICATION FORMS OF INTRAOPERATIVE NERVE MONITORIZATION}

International Intraoperative Monitoring Study Group emphasized that INOM could be applied for 3 main purposes (3).
Finding RLN (Neural Mapping): Early and complete identification of the recurrent laryngeal nerve is an important step in preventing unintended nerve injuries. RLS is located and mapped in the paratracheal region by stimulation with nerve monitoring probe (Picture-7). After that, the nerve is seen by dissection directly in the region where stimulation is obtained. The rate of finding the nerve in IONM studies is between $98-100 \%(10)$. In this context, Chiang et al. (23) reported that IONM and RLN could be revealed $100 \%$, and that $26 \%$ of these nerves consisted of difficult-to-determine nerves. Anuwong et al. (24) in a large series which the thyroidectomies were performed by an experienced

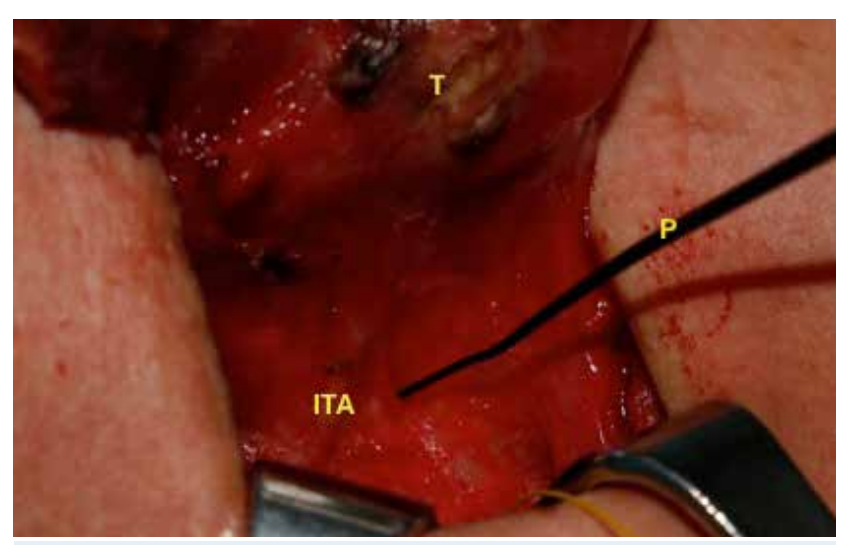

Picture-7: Probe stimulation of possible area to find recurrent laryngeal nerve before dissection in thyroid region (ITA: Inferior thyroid artery, T: Thyroid, P: Probe)

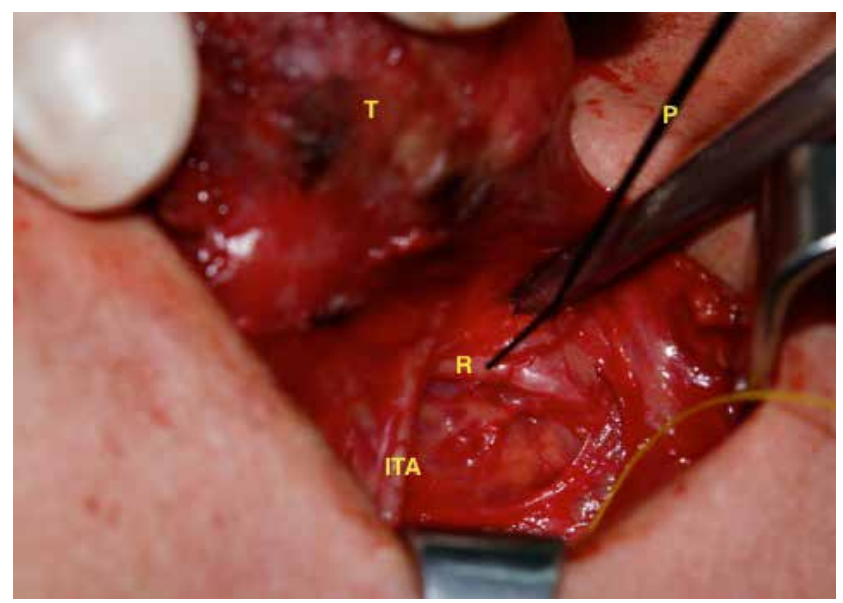

Picture-8: Stimulation of recurrent laryngeal nerve after it is found and presented (R1), and stimulation to reveal the trace of the nerve (ITA: Inferior thyroid artery, T: Thyroid, P: Probe, R: Recurrent laryngeal nerve) 
endocrine surgeon that RLN can be determined with eyes with a rate of $93.2 \%$ before IONM application, it can be determined with a rate of $97.9 \%$ in the period in which standard IONM steps are not applied, and this rate goes up to $100 \%$ when standard IONM is applied.

Helping Dissection: In this method, RLN is found first. Then, the nerve and neighboring tissues are stimulated with electrodes intermittently and the nerve and its branches are tried to be revealed in the field of dissection (Picture-8). The contribution of the IONM to the determination of the medial border of the nerve during dissection in the Berry ligament region is particularly important (25). In this context, when there is bleeding in the Berry's ligament region, careless clamping or electrocautery should not be used in the region to avoid RLN injury. After the dissection is complete, the RLS is stimulated at the most proximal point (R2) (Picture-9).

\section{Predicting Postoperative Nerve Function and} Determining The Location of The Lesion: There are no methods that can detect a damaged segment in cases where nerve monitoring is not used. With IONM, even if the nerve is determined to be visually intact, it is understood that the nerve is whether

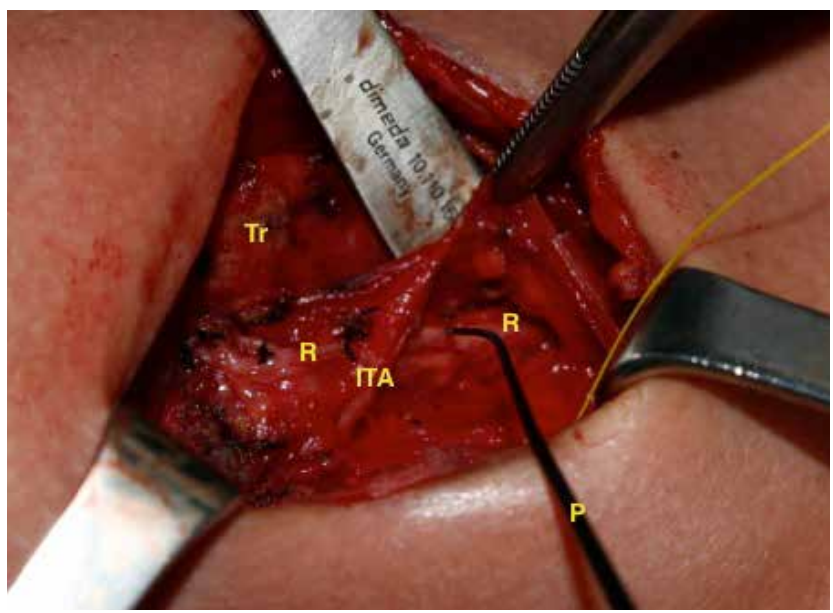

Picture-9: Proximal stimulation of the recurrent laryngeal nerve in the region after completion of dissection and bleeding control in the thyroid region (R2) (ITA: Inferior thyroid artery, Tr: Trachea, P: Probe, R: Recurrent laryngeal nerve) functional or not and the location of the damaged segment can be detected. If the loss of function is due to dissection of the nerve, repairs can also be performed simultaneously. In the metaanalysis in 2008, in which six broad studies were evaluated; the sensitivity of nerve monitoring was $24-85 \%$ in predicting the postoperative nerve function, the specificity was $94-99.7 \%$, the positive predictive value was $30-92 \%$, the negative predictive value was $91-100 \%$ and its total compliance was $95 \%$ (26). Reasons for differences in these rates were; - Using different variables in IONM evaluation (some studies have considered post-dissection RLN stimulation (R2), and some have considered vagus stimulation (V2)),

- Differences in the method of nerve monitoring used,

- Type of recording electrodes used,

- Nerve monitoring to be performed continuously or intermittently.

The way to prevent them is the standardization of monitoring as in Table-2. Postoperative vagus stimulation (V2) (Picture-10) is the most sensitive test to predict the postoperative vocal cord function $(3,19,27)$. In two recent studies published in accordance with the standards, the sensitivity of

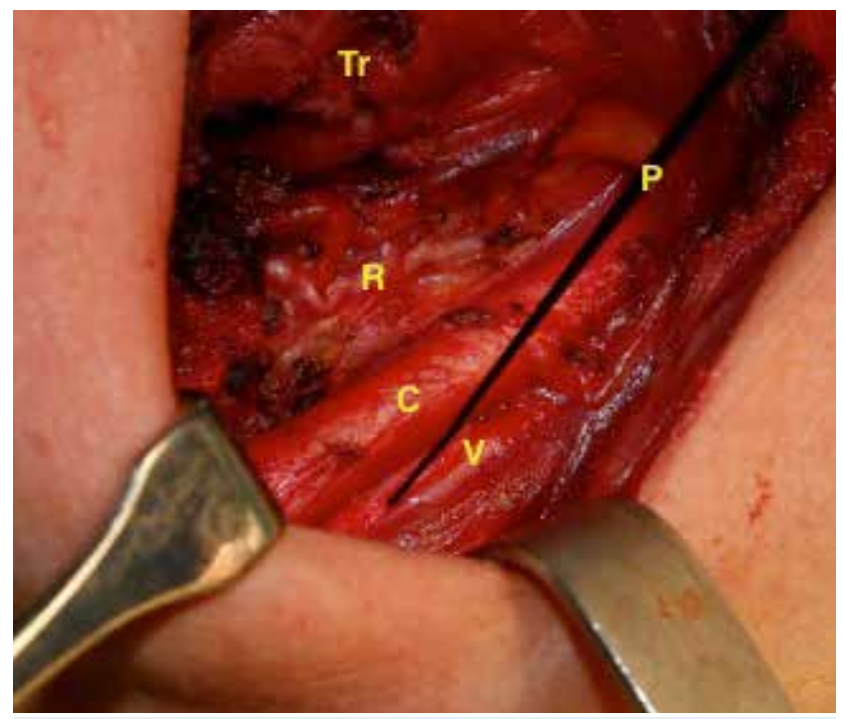

Picture-10: Stimulation of ipsilateral probe after the interventions on the thyroid region are finished (V2) (C: Common carotid artery, P: Probe, R: Recurrent laryngeal nerve, Tr: Trachea) 
intermittent IONM was reported to be $74-92 \%$, specificity 99.3-99.5\%, positive predictive value 76.7-77\% and negative predictive value 99.4$99.8 \%$. Especially with standardization the increase in sensitivity and specificity is remarkable. With continuous vagus stimulation, the sensitivity of IONM was $90.9 \%$, specificity $99.5 \%$, positive predictive value $88.2 \%$, and negative predictive value $99.8 \%(28,29)$. When it is determined that the nerve is not functional with the IONM, intervention to the contralateral lobe becomes important, and the surgeon can delay this procedure and prevent bilateral vocal cord paralysis.

\section{CAUSES OF FALSE POSITIVE AND FALSE NEGATIVE RESULTS IN NERVE MONITORING}

Here, some definitions will be referred to in order to avoid confusion. Positive test $(+)$, is the signal loss at the end of surgery. Negative test (-), is to continuation of the signals (EMG waveforms) obtained by nerve stimulation at the end of the surgical operation (25). False positivity, is the signal loss at the end of the surgical procedure (positive test) and postoperative vocal cord function to be normal. False negativity, is the postoperative vocal cord paralysis despite the receipt of appropriate EMG waveforms with nerve stimulation at the end of the surgical operation. As discussed above, the high negative predictive value obtained in many studies makes the IONM superior to the visualization with eyes in predicting the postoperative vocal cord function, especially the normal vocal cord function. However, some problems that may occur during monitoring can lead to incorrect results (3).

\section{Reasons for False Positivity (3):}

- Problems with device and its attachments: The most common reason is that the endotracheal tube with surface electrode is not placed in the proper position or the tube is displaced.

- Blood and fascia prevent the stimulation of the nerve segment.

- Continuation of neuromuscular block.

- Fast healing of the resulting neuropraxia.

\section{Reasons for False Negativity (3):}

- Stimulation of the injured nerve segment at its distal. This can be avoided by the application of standard IONM rules and by receiving stimulation from the vagus at the end of the operation.

- Injury due to additional manipulations performed in the region before and after closing, following the last test.

- Development of delayed neuropraxia due to progressive edema or delayed vascular effect.

- Injury of the back branch with motor function, especially in the branched nerves (30).

- Vocal cord paralysis can be caused by nonneural causes such as laryngeal edema, arytenoid cartilage dislocation.

\section{RECURRENT LARYNGEAL NERVE MONITORING WITH CONTINUOUS VAGUS PROBE}

Intermittent IONM has some limitations. In this method, the IONM only informs about the moment that the nerve is stimulated with the probe and function of the distal of the point where the nerve is stimulated. It does not give information about the effect of the manipulations performed until the next stimulation of the nerve. If these manipulations cause a nerve injury, the next stimulation may provide intraoperative information about the damage that these manipulations have on the nerve. In addition, intermittent IONM applications may differ, and vagus stimulation is not available at centers that do not perform standard IONM. This can affect postoperative predictive value and outcomes. In order to overcome these limitations of the intermittent IONM, continuous IONM has become into question.

Continuous stimulation of the IONM with a probe applied to the vagus before the RLN is separated from vagus allows the surgeon to constantly follow the RLN function while dissecting the thyroid (Picture-11) (3). The most common cause of RLN injuries is tractional trauma (31). Significant loss of signal and vocal cord paralysis in the RLN can be prevented, especially when the traction-causing action is changed at a specific 


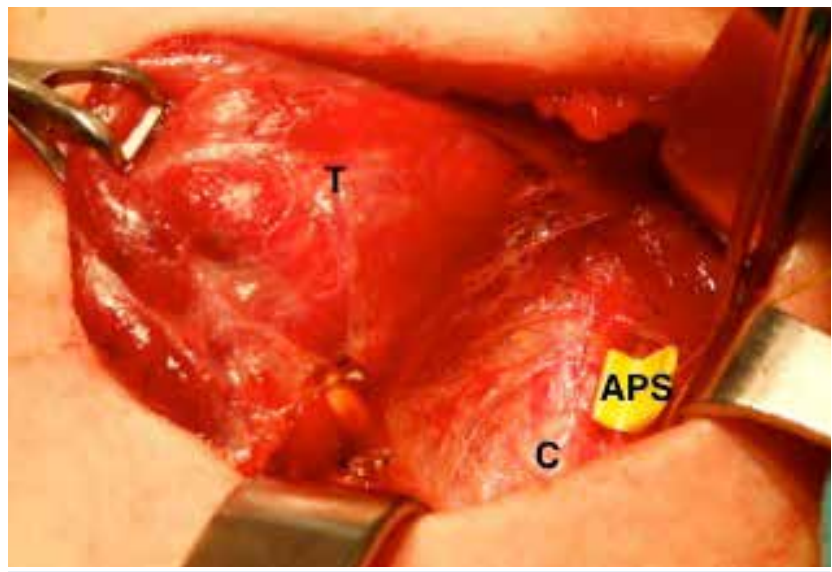

Picture-11: Application of continuous stimulation probe (APS) to vagus (APS: Automatic periodic stimulation, C: Common carotid artery, T: Thyroid)

stage. The goal of continuous vagus probing is to inform the surgeon immediately of any critical changes to the stimulation values in the RLN and to avoid signal loss and vocal cord paralysis with the measures to be taken. In studies, a 50\% decrease in amplitude and a $10 \%$ increase in latency time were defined as critical stimulating changes (Figure-3) $(32,33)$. Accordingly, these values are adjusted in neuromonitoring devices. The device alarms when the amplitude falls below $50 \%$ of the value of the initial setup and/or the latency time increases by more than $10 \%$. The intermittent IONM probe or intermittent IONM technique is not a separate process from the continuous IONM process. The intermittent IONM probe is a complementary and integral part of the continuous IONM technique. In the instrument setup, both the standard probe and the continuous vagus probe are connected. The ability to predict the action that could lead to signal loss on the RLN is more pronounced in the CONTINUOUS IONM than the intermittent IONM (34). Signal changes can be reversed above $70 \%$ when the action that caused the signal decrease before the loss of signal is terminated $(33,35)$. The follow up of signal recovery can be done much better at continuous IONM than intermittent IONM. In addition, permanent RLN paralysis is significantly reduced by continuous IONM compared to intermittent IONM $(24,34)$.

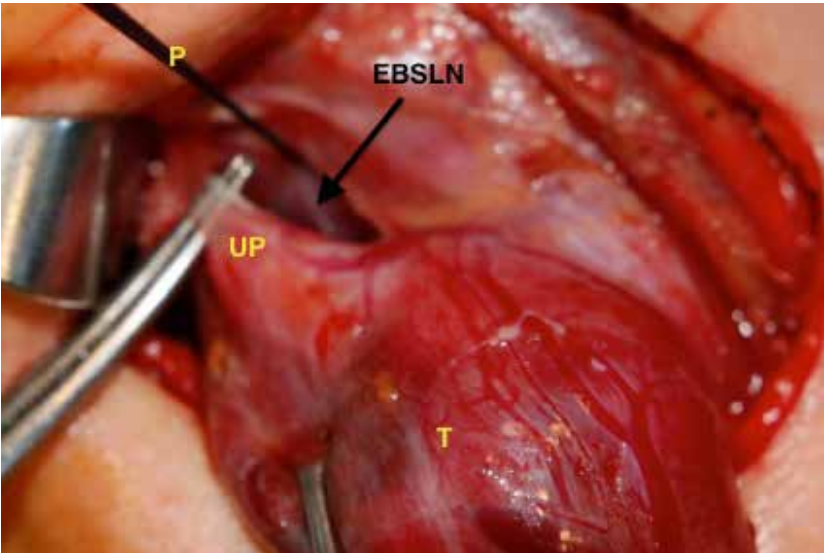

Picture-12: Finding EBSLN with probe in the cricothyroid space during the dissection of upper pole of thyroid (P: Probe, EBSLN: External Branch of the Superior Laryngeal Nerve, T: Thyroid, UP: Upper pole

\section{MONITORING OF THE EXTERNAL BRANCH OF SUPERIOR LARYNGEAL NERVE}

With nerve stimulation, the contraction of the cricothyroid muscle, which is located primarily on the surgical site and which EBSLN is its motor nerve of, is evaluated (10). In humans, the nerve called the human communicating nerve, which is a branch of EBSLN, innerves the $1 / 3$ anterior portion of the thyroarytenoid muscle, which is the adductor muscle of the vocal cord, and anastomoses with RLN in this region. In the anatomy studies, $41-85 \%$ of human communicating nerve was detected (36-38). This finding also supports IONM studies on EBSLN. A positive electromyographic waveform of $68-80 \%$ was obtained from the vocal cord when EBSLN stimulation was performed with a standard endotracheal tube (39-41). Intraoperative neuromonitoring makes a significant contribution to the visual and functional detection of EBSLN (Picture-12) (42). Uludag etal. (43) in their prospectively randomized study showed that IONM significantly reduced the rate of injury to EBSLN objectively by intraoperative cricothyroid muscleEMG. Intraoperative neuromonitoring reduces early postoperative voice changes related to EBSLN $(41,44)$.

Intraoperative neuromonitoring is an important method that contributes to the thyroidectomy in many ways and increases the standards of thyroidectomy, together with significant contribution in the finding and functional evaluation of both RLN and EBSLN. 


\section{REFERENCES}

1. Hermann M, Alk G, Roka R, Glaser K, Freissmuth M. Laryngeal recurrent nerve injury in surgery for benign thyroid diseases: effect of nerve dissection and impact of individual surgeon in more than 27,000 nerves at risk. Ann Surg 2002; 235: 261-8. [CrossRef]

2. Bergenfelz A, Jansson S, Kristoffersson A, Mårtensson H, Reihnér $E$, Wallin $G$, et al. Complications to thyroid surgery: results as reported in a database from a multicenter audit comprising 3,660 patients. Langenbecks Arch Surg 2008; 393: 667-73. [CrossRef]

3. Randolph GW, Dralle $\mathrm{H}$; International Intraoperative Monitoring Study Group, Abdullah H, Barczynski M, Bellantone R, Brauckhoff $M$, et al. Electrophysiologic recurrent laryngeal nerve monitoring during thyroid and parathyroid surgery: international standards guideline statement. Laryngoscope 2011; 121(Supp/1): S1-16. [CrossRef]

4. Shedd DP, Durham C. Electrical identification of the recurrent laryngeal nerve. I. Response of the canine larynx to electrical stimulation of the recurrent laryngeal nerve. Ann Surg 1966; 163: 47-50. [CrossRef]

5. Uludağ $M$, işgör A. Intraoperatif sinir monitorizasyonu teknik ayrıntılar. İsgör A, Uludağ M (editör). Tiroit. 1. Baskı. İstanbul: Nobel Tıp Kitabevleri, 2013.p.917-31.

6. Randolph GW. Surgical anatomy of the recurrent laryngeal nerve. In: Randolph GW (ed). Surgery of the Thyoid and Parathyroid Glands. $1^{\text {st }}$ ed. Philadelphia: W.B. Saunders; 2003.p.300-42.

7. Sturgeon $C$, Sturgeon $T$, Angelos P. Neuromonitoring in thyroid surgery: attitudes, usage patterns, and predictors of use among endocrine surgeons. World J Surg 2009; 33: 417-25. [CrossRef]

8. Ho Y, Carr MM, Goldenberg D. Trends in intraoperative neural monitoring for thyroid and parathyroid surgery amongst otolaryngologists and general surgeons. Eur Arch Otorhinolaryngol 2013; 270: 2525-30. [CrossRef]

9. Dralle H, Sekulla C, Lorenz K, Nguyen Thanh P, Schneider R, Machens A. Loss of the nerve monitoring signal during bilateral thyroid surgery. Br J Surg 2012; 99: 1089-95. [CrossRef]

10. Barczyński M, Randolph GW, Cernea CR, Dralle H, Dionigi G, Alesina $P F$, et al. External branch of the superior laryngeal nerve monitoring during thyroid and parathyroid surgery: International Neural Monitoring Study Group standards guideline statement. Laryngoscope 2013; 123(Supp/ 4): S1-14. [CrossRef]

11. Dionigi G, Bacuzzi A, Boni L, Rovera F, Dionigi R. What is the learning curve for intraoperative neuromonitoring in thyroid surgery? Int J Surg 2008; 6(Supp/ 1): S7-12. [CrossRef]

12. Jonas J, Bähr R. Intraoperative neuromonitoring of the recurrent laryngeal nerve - results and learning curve. Zentralbl Chir 2006; 131: 443-8. [CrossRef]

13. Pragacz K, Barczyński M. Evaluation of the learning curve for intraoperative neural monitoring of the recurrent laryngeal nerves in thyroid surgery. Pol Przegl Chir 2015; 86: 584-93. [CrossRef]

14. Lu IC, Wu CW, Chang PY, Chen HY, Tseng KY, Randolph GW, et al. Reversal of rocuronium-induced neuromuscular blockade by sugammadex allows for optimization of neural monitoring of the recurrent laryngeal nerve. Laryngoscope 2016; 126: 1014-9. [CrossRef]

15. Kim HY, Tufano RP, Randolph G, Barczyński M, Wu CW, Chiang FY, et al. Impact of positional changes in neural monitoring endotracheal tube on amplitude and latency of electromyographic response in monitored thyroid surgery: Results from the Porcine Experiment. Head Neck 2016; 38(Suppl 1): E1004-E1008. [CrossRef]
16. Barber $S R$, Liddy $W$, Kyriazidis $N$, Cinquepalmi $M$, Lin $B M$, Modi $R$, et al. Changes in electromyographic amplitudes but not latencies occur with endotracheal tube malpositioning during intraoperative monitoring for thyroid surgery: Implications for guidelines. Laryngoscope 2016 Nov 16. [Epub ahead of print] [CrossRef]

17. Yap SJ, Morris RW, Pybus DA. Alterations in endotracheal tube position during general anaesthesia. Anaesth Intensive Care 1994; 22: 586-8.

18. Chambers KJ, Pearse A, Coveney J, Rogers S, Kamani D, Sritharan $N$, et al. Respiratory variation predicts optimal endotracheal tube placement for intra-operative nerve monitoring in thyroid and parathyroid surgery. World J Surg 2015; 39: 393-9. [CrossRef]

19. Chiang FY, Lee KW, Chen HC, Chen HY, Lu IC, Kuo WR, et al. Standardization of intraoperative neuromonitoring of recurrent laryngeal nerve in thyroid operation. World J Surg 2010; 34: 223-9. [CrossRef]

20. Dionigi G, Bacuzzi A, Boni L, Rovera F, Rausei S, Frattini F, et al. The technique of intraoperative neuromonitoring in thyroid surgery. Surg Technol Int 2010; 19: 25-37.

21. Dionigi G, Kim HY, Randolph GW, Wu CW, Sun H, Liu X, et al. Prospective validation study of Cernea classification for predicting EMG alterations of the external branch of the superior laryngeal nerve. Surg Today 2016; 46: 785-91. [CrossRef]

22. Scheneider R, Sekulla C, Machens A, Lorenz K, Nguyen-Thanh $P$, Dralle $H$. Dynamics of loss recovery of the nerve monitoring signal during thyroidectomy predict early postoperative vocal fold function. Head Neck 2016; 38(Suppl 1): E1144-E1151. [CrossRef]

23. Chiang FY, Lu IC, Chen HC, Chen HY, Tsai CJ, Lee KW, et al. Intraoperative neuromonitoring for early localization and identification of recurrent laryngeal nerve during thyroid surgery. Kaohsiung J Med Sci 2010; 26: 633-9. [CrossRef]

24. Anuwong A, Lavazza M, Kim HY, Wu CW, Rausei S, Pappalardo $V$, et al. Recurrent laryngeal nerve management in thyroid surgery: consequences of routine visualization, application of intermittent, standardized and continuous nerve monitoring. Updates Surg 2016; 68: 331-41. [CrossRef]

25. Randolph GW. Surgical anatomy and monitoring of the recurrent laryngeal nerve. In: Randolph GW (ed). Surgery of the Thyoid and Parathyroid Glands. 2nd ed. Philadelphia: Elsevier Saunders; 2012.p.306-40.

26. Dralle H, Sekulla $C$, Lorenz $K$, Brauckhoff $M$, Machens A; German IONM Study Group. Intraoperative monitoring of the recurrent laryngeal nerve in thyroid surgery. World I Surg 2008; 32: 1358-66. [CrossRef]

27. Dionigi G, Chiang FY, Rausei S, Wu CW, Boni L, Lee KW, et al. Surgical anatomy and neurophysiology of the vagus nerve (VN) for standardised intraoperative neuromonitoring (IONM) of the inferior laryngeal nerve (ILN) during thyroidectomy. Langenbecks Arch Surg 2010; 395: 893-9. [CrossRef]

28. Schneider R, Sekulla C, Machens A, Lorenz K, Nguyen Thanh P, Dralle $H$. Postoperative vocal fold palsy in patients undergoing thyroid surgery with continuous or intermittent nerve monitoring. Br J Surg 2015; 102: 1380-7. [CrossRef]

29. Stopa M, Barczyński M. Prognostic value of intraoperative neural monitoring of the recurrent laryngeal nerve in thyroid surgery. Langenbecks Arch Surg 2016 May 3. [Epub ahead of print] [CrossRef]

30. Uludag M, Aygun N, Isgor A. Motor function of the recurrent laryngeal nerve: Sometimes motor fibers are also located in the posterior branch. Surgery 2016; 160: 153-60. [CrossRef] 
31. Dionigi G, Wu CW, Kim HY, Rausei S, Boni L, Chiang FY. Severity of recurrent laryngeal nerve injuries in thyroid surgery. World j surg 2016; 40: 1373-81. [CrossRef]

32. Schneider R, Przybyl J, Pliquett U, Hermann M, Wehner M, Pietsch UC, et al. A new vagal anchor electrode for real-time monitoring of the recurrent laryngeal nerve. Am J Surg 2010; 199: 507-14. [CrossRef]

33. Schneider R, Randolph GW, Sekulla C, Phelan E, Bucher $M$, Thanh $\mathrm{PH}$, et al. Continuous intraoperative vagus nerve stimulation for identification of imminent recurrent laryngeal nerve injury. Head Neck 2013; 35: 1591-8. [CrossRef]

34. Jonas J, Boskovic A. Intraoperative neuromonitoring (IONM) for recurrent laryngeal nerve protection: Comparison of intermittent and continuous nerve stimulation. Surg Tecnol Int 2014; 24: 1338.

35. Phelan E, Schneider $R$, Lorenz $K$, Dralle $H$, Kamani D, Potenza $A$, et al. Continuous vagal IONM prevents recurrent laryngeal nerve paralysis by revealing initial EMG changes of impending neuropraxic injury: a prospective, multicenter study. Laryngoscope 2014; 124: 1498-505. [CrossRef]

36. Wu BL, Sanders I, Mu L, Biller HF. The human communicating nerve. An extension of the external superior laryngeal nerve that innervates the vocal cord. Arch Otolaryngol Head Neck Surg 1994; 120: 1321-8. [CrossRef]

37. Maranillo E, Leon X, Quer M, Orus C, Sanudo JR. Is the external laryngeal nerve an exclusively motor nerve? The cricothyroid connection branch. Laryngoscope 2003; 113: 525-9. [CrossRef]

38. Mu L, Sanders I. The human cricothyroid muscle: three muscle bellies and their innervation patterns. J Voice 2009; 23: 21-8. [CrossRef]
39. Potenza AS, Phelan EA, Cernea CR, Slough CM, Kamani DV, Darr $A$, et al. Normative intra-operative electrophysiologic waveform analysis of superior laryngeal nerve external branch and recurrent laryngeal nerve in patients undergoing thyroid surgery. World J Surg 2013; 37: 2336-42. [CrossRef]

40. Barczyński M, Konturek A, Stopa M, Honowska A, Nowak $W$. Randomized controlled trial of visualization versus neuromonitoring of the external branch of the superior laryngeal nerve during thyroidectomy. World I Surg 2012; 36: 1340-7. [CrossRef]

41. Uludag M, Aygun N, Kartal K, Besler E, Isgor A. Is intraoperative neural monitoring necessary for exploration of the superior laryngeal nerve? Surgery 2016 Dec 15. [Epub ahead of print] [CrossRef]

42. Aygün N, Besler E, Celayir F, Bozdağ E, Çitgez B, Yetkin $G$ ve ark. Süperior laringeal sinirin eksternal dalı'nın belirlenmesinde intraoperatif sinir monitorizasyonunun etkisi ve sinirin tiroaritenoid kasın motor fonksiyonuna katkısı. Şişli Etfal Hastanesi Tıp Bülteni 2016; 50: 97-102.

43. Uludag M, Aygun N, Kartal K, Citgez B, Besler E, Yetkin G, et al. Contribution of intraoperative neural monitoring to preservation of the external branch of the superior laryngeal nerve: a randomized prospective clinical trial. Langenbecks Arch Surg. 2016 Dec 29. [Epub ahead of print] [CrossRef]

44. Barczyński M, Konturek A, Stopa M, Honowska A, Nowak $W$. Randomized controlled trial of visualization versus neuromonitoring of the external branch of the superior laryngeal nerve during thyroidectomy. World I Surg 2012; 36: 1340-7. [CrossRef] 